\section{Re-discovering the Semantics of אמן in Qal*}

\author{
Dempsey Rosales Acosta**
}

RECIBIDO: 20-04-16. APROBADO: 24-11-16

\begin{abstract}
АвSTRACT: This study presents a philological and semantic essay of the verb אָָ in order to uncover the semantic Wortfeld of its qal conjugation. The most of philological and exegetic studies omit the analysis of this conjugation because they consider it insignificant and without any semantic value. Thus, they focus their studies on the nifal and hifil forms as the basic semantic platform that permeates all the grammatical forms of the shoresh אמן. This essay proposes a different opinion. The qal form is the primeval semantic substratum that permeates all the grammatical forms of the lexeme אמן, becoming the semantic platform upon which the meanings of the nifal and hifil conjugations are built.
\end{abstract}

Key words: 'āman, qal, Protection, Parents, Cognitive Semantics.

\section{Redescubrir el valor semántico de המ in qal}

Resumen: El estudio presenta un ensayo filológico y semántico del verbo אָּ con el fin de resaltar el valor semántico de su Wortfeld en la conjugación qal. La mayoría de los estudios filológicos y exegéticos ha omitido el análisis de este lexema en qal al haberlo considerado marginal, ya que sus investigaciones enfatizan las formas nifal e hifil del lexema como la plataforma semántica básica que impregna todas las formas gramaticales del shoresh אמן. En este ensayo se propone una opinión diversa. La conjugación qal presentaría el sustrato semántico primitivo que impregna todas las formas gramaticales del lexema אמן, que se convierte en la plataforma semántica sobre la cual se construyen los significados de las formas nifal y hifil de la raíz en estudio.

Palabras clave: 'àman, qal, protección, padres, semántica cognitiva.

\section{PARA CITAR ESTE ARTÍ́CULO:}

Rosales Acosta, Dempsey. "Re-discovering the Semantics of אמן in Qal'. Theologica Xaveriana 184 (2017): 431-460. https:// doi.org/10.11144/javeriana.tx67-184.rsq

\footnotetext{
* The present biblical essay is the result of a philological and semantic research for a conference presented at the Pastoral Theological Congress on the Year of the Faith at the Pontifical Seminary of Thomas Aquinas of Santo Domingo, Dominican Republic.

** The author obtained a Biblical Theology Doctorate (STD) from the Pontifical Gregorian University, Rome. Since 2010, he has been working as a full time faculty member of the Theology Department of the University of St. Thomas, Houston (TX). OrCid: 0000-0003-2040-5569. E-mail: drosale@stthom.edu
} 


\section{Introduction}

The Sacred Scripture articulates in a theological manner diverse phenomenological manifestations of conviction and security encountered through an experiential relationship with God. ${ }^{1}$ It is necessary, therefore, to elucidate and clarify the basic meaning of the Old Testament vocabulary that has been used by the original authors in order to express their personal relationship with YHWH in concrete historical contexts. These "facts of language are interpreted from the perspective of a usagebased model, according to which language is built from actual usage events". ${ }^{2}$

Such historical contexts with its respective linguistics usage imply, other than the moment of the revelation itself, a way of expression of the revealed truth through the faith of Israel as it evolved from the moment of its concrete experience until it had been conveyed within fixed theological and linguistic notions.

Following this methodological reasoning, the semantic analysis of the vocabulary of faith employed by the hagiographers must be the essential platform on which to discover its theological value. The semantic examination uncovers the original semantic nucleus of the verb אָָ in its proper context while determining its most original message according to the real intention of the author manifested in the qal forms. It is important to clarify that a lexeme manifested in different binyamin, as it is the case of nifal and hifl, can adopt different semantic levels that are not necessarily related or derived from the qal. However, in the case of the root there has been a philological debate in order to elucidate its original meaning.

Alfred Jepsen encounters this issue exposing the possible archaic meanings of the root, using comparative analysis with different languages such as Arabic, Aramaic, and Syriac. ${ }^{3} \mathrm{He}$ indicates that the lexeme has a strong connection with the Arabic 'amina that can conjointly signify "secure" and "faithful". The same term implied the equivalent in the meaning of qal and nifal, not excluding each other, since one meaning includes the other. ${ }^{4}$ Therefore, Jepsen in his philological analysis supports

\footnotetext{
${ }^{1}$ Vatican Council II, “Dogmatic Constitution Dei Verbum, on Divine Revelation” 12; Janda, "Cognitive Linguistics in the year 2015", 135.

2 Janda, “Cognitive Linguistics in the year 2015”, 131.

${ }^{3}$ Jepsen affirms that "when we do not know the original meaning, the development of a word can lead us far from that meaning to something entirely different" (Jepsen, "אָָָׁ", 293).

${ }^{4}$ Ibid., 292-293. Koehler and Baumgartner do not see this semantic correlation implied in the same root of אמן. They suggest two different lexemes. The first lexeme (אמן (I) presents the basic meanings "to be firm, trustworthy, and safe". This root does not imply the same meanings in qal, manifesting the diverse semantic variations expressed in nifal and hifll. The second lexeme (II אמן) predominately expresses the meanings of qal, namely, protection, care, security, nurse, protector, etc. The philological position
} 
the semantic value of qal as one of the essential manifestations in the meaning of the root in order to clarify its fundamental meanings. ${ }^{5}$

Therefore, the current essay presents a semantic analysis of the verb of under the approach of Sachexegese ${ }^{6}$, in order to highlight its theological meanings and interpretation that express an essential aspect of the semantic analysis. Using this methodological approach emphasizes the effort to interpret the verb אָָ in light of the central concern of the biblical texts, which are theological in nature. Consequently, the present semantic methodology offers a synchronic and diachronic Semasiology of the aforementioned verb that goes beyond the simplistic lexicographic analysis of the studied term. ${ }^{8}$

As one of the branches of semantics, Semasiology studies a specific word or lexeme starting from its form, then analyzes and decodes the diverse meanings associated with it throughout the different texts and historical contexts in which a term may appear. Semasiology also studies the semantic changes of a term, as it is in the particular case of the shoresh in order to determine its semantic changes. If we cannot first establish which is its most fundamental meaning, then it would be difficult to use it as a point of reference to determine alternative added meanings applied throughout specific historical contexts.

While this essay does not pretend to offer a solution to this philological problem, its purpose is to reconsider the semantic value of $q$ al as a substratum or source domain for the interpretation of the different binyanim. The synchronic approach presented in this essay does not exclude the diachronic dimension of the theological notions of the Old Testament. Such notions can imply a transformation of meaning that goes

of Brown, Driver, Briggs, Gesenius and Jepsen disagree with the aforementioned division of these two stems, suggesting a unique shoresh that implies a rich semantic spectrum. See Koehler, Baumgartner, and Stamm, "Iמן" אממןץ", I, 63-64-59; Brown, Driver, and Briggs, Hebrew and English Lexicon of the Old Testament: "אָמֵן", 52-53.

5epsen, "אָמָן", 293-294. The same methodological path is followed by Juan Alfaro, who acknowledges the predominance of אמן in nifal and hifil as expressions of faith, but he began his analysis positing the basic meanings of אמן in qal, and affirming its fundamental meanings are nurture, protection, and caring. Alfaro establishes the fundamental semantic value of qal in order to elucidate the meanings of the other binyanim and cognate nouns of the studied root in order to have a semantic map of the shoresh. See Alfaro, "Fides in terminologia biblica", 463-464.

6 "Sachexegese designates the effort to interpret the words of the Bible in light of the Bible's own central concern, i. e., God. The term is approximately equivalent to theological exegesis of theological interpretation." (Soulen and Soulen, Handbook of Biblical Criticism, 165)

${ }^{7}$ Ibid., 165-166.

${ }^{8}$ Andrason and Van der Merwe, "The Semantic Potential of Verbal Conjugations as set of Polysemous Senses", 74. 
from a concrete and objective meaning of "protection, care, and security" to a more abstract and theological meaning that implies "faith, trust, or faithfulness". ${ }^{9}$ However, using the semantic analysis of significant pericopes, it is possible to identify the most important theological meanings of the primeval semantic substratum of its qal conjugation that permeates the different morphosyntactic variations of the root.$^{10}$

\section{The verb אמֵַן as lexis of faith}

In the books of the Old Testament ${ }^{11}$, the most important vocabulary ${ }^{12}$ to express the notion of faith derives from the Hebrew root This philological root cannot be found attested in Akkadian, Ugaritic, and Phoenician, but it has a great variety of semantic nuances in the biblical Hebrew ${ }^{13}$, depending upon the conjugation and literary context in which the root is employed in the biblical narrative. According to this line of argumentation, I would like to highlight the assertion of Moberly, who affirms:

${ }^{9}$ T. C. Vriezen interprets the lexeme אמן as presenting the basic meaning of "holding" or "bearing," which are the basic connotations expressed in the participle forms of the root in qal. Vriezen uses these basic meanings in order to provide the starting point from which the meanings of the other conjugations derive (Vriezen, Geloven en Vertrouwen, 12-13, in Eichrodt, Theology of the Old Testament, II, 276, Note 2 of the same page). See the tentative of translation and interpretation of the hifl form of $\mathrm{k}$ using the qal semantic connotations in Von Rad, Teologia dell'Antico Testamento 1, 202-203; Eichrodt, Theology of the Old Testament, II, 276, especially Note 2. For a diachronic analysis of the notion of faith in the Old Testament, see Eichrodt, Theology of the Old Testamnent, II, 277-290.

${ }^{10}$ Nöth, Handbook of Semiotics, 106; Soulen and Soulen, Handbook of Biblical Criticism, 170. Verburg talks about Semasiology as an intellectual game of hide and seek in which the Jewish and Christian exegetes make the effort to discover the true meanings embraced in the words of the Scripture (Verburg, Language and its Functions, 29-30).

${ }^{11}$ The Masoretic text used is from Karl Elliger and Wilhelm Rudolph (dir.), Biblia Hebraica Stuttgartensia (Stuttgart: Deutsche Bibelgesellschaft, 1997).

${ }^{12}$ The vocabulary of faith is not limited to the philological family of the Hebrew root of אמן. There are other important terms that signify the experience of faith, e.g., the verb דָָָָ "to trust" (Deut 33,12) and ירָ "to fear, to respect." The latter verb is used to signify moral obedience and religious obligation (Gen

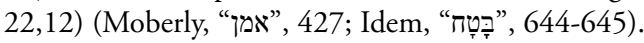

${ }^{13}$ Wildberger, "אמן", 134. Koehler and Baumgartner propose two different roots with the same consonants in Hebrew. According to these authors, the first root (אמן) conveys the traditional Hebrew definition of "to be firm, to be secure, to be stable, etc. This root only appears in passive participle in qal, while the nifal and hifil conjugated forms predominate in the Hebrew texts. The second root (אמן) comes from the Akkadian word ummānu, and according to Koehler, Baumgartner and Albright this root is the source from which all the active participles in qal, used in the MT, come from (see Num 11,12; Isa 49,23; $2 \mathrm{Kgs}$ 10,1.5; Esther 2,7; 2 Sam 4,4; Ruth 4,16). The aforementioned authors, at the moment of translating the second root, proposed the same semantic value of the first root. See Koehler, Baumgartner, and Stamm "אמן", I, 63-64; Albright, "A Prince of Taanach of the Fifteenth Century", 18, Note 28. The latter opinion does not convince many scholars and philologists as it is the case of Jepsen and Moberly, who proposed only one Hebrew root, rejecting the opinion of Koehler, Baumgartner and Albright. See Jepsen, "אמאן", 294; 227-428. 
There are five forms of the 'mn root that are of theological significance: the two related nouns 'emet and 'emûnâ, the adverb, 'àmèn, and the two forms of the verb ne'emān (ni.) and he'emîn (hi.). Other forms either have no special theological significance or have a significance that is similar to, and probably a derivative from the five forms described here. ${ }^{14}$

Moberly's opinion represents the predominant academic line of thought that is also attested to in the considerable work of Wildberger. ${ }^{15}$ For the majority of biblical exegetes, as are the two aforementioned important authors, the most significant verbal forms of the root אמן are ne'emān (nifal) and he'emîn (bifil) as the fundamental forms of the root in the Old Testament.

Without denying the significant biblical contributions in the elucidations of the shoresh in nifal and hifil, I was compelled to focus my attention on the semantic and theological importance of the qal conjugation. The majority of the exegetes consider the qal conjugation of אמן as having no significance under the theological and semantic dimension of faith as manifested within the narratives of the Old Testament. Thus, many biblical and theological articles do not dedicate any comments or references to the qal conjugation of the verb ${ }^{16}$

Following this line of thought, the reader could infer from this predominant academic line of thought the nifal and hifl conjugations of אמן are the original and basic semantic platform upon which the other semantic nuances, manifested in other conjugations of the same verb, find their respective references, e.g., hofal, piel, pual, hithpael, and even qal. Therefore, the complete silence or omission of the qal form of the verb indicates that its meaning could be equal to or equivalent to the meanings expressed in nifal and hifil.

Noticing this deafening silence of the analysis of the verb אמָ in qal in academia, the following logical queries emerged: Is qal identical to nifal and hifil regarding the verb אָמֵ and for this reason is omitted? Do nifal and hifil of expes the primordial meaning of the verb?

It is important to acknowledge that the semantic values of one conjugation can be found expressed in other conjugations of the same verb throughout the different semantic nuances that the Semitic authors used in order to express the deep spectrum of their cultural and religious experience. Using this rationale, it is academically imperative to establish with precision the primordial verbal meaning that expresses

${ }^{14}$ Ibid., 428.

${ }^{15}$ Wildberger, "אמן", 134-157.

${ }^{16}$ Moberly, "אמן", 427-433; Wildberger, "אמן" 134-157; Idem, “Glauben im AT”, 129-159. 
the basic semantic domain in order to rediscover the elementary meaning manifested in a subtle manner in the different Hebrew verbal conjugations.

In the field of Biblical Hebrew syntax, it is traditionally accepted that the simplest conjugation is qal, which literally means "light". ${ }^{17}$ This conjugation conveys the simplest action implied in the verb at the most basic semantic level (Grundstamm). According to this logical path, Joüon and Muraoka affirm that "the derived or augmented conjugations have an expanded form in relation to the simple conjugation, and the action which they express has an added objective modality." ${ }^{18}$ These same authors affirm that the nifal is "the reflexive conjugation of the simple action"19, implying that the same semantic level of qal remains in a certain manner but under a different aspect.

The hifil, on the other hand, is the active conjugation of causative action. ${ }^{20}$ The hifil generally has to do with the causing of an event and as a consequence, "the object participates in the event denoted by the verbal root". ${ }^{21}$ Therefore, following the logic of Joüon and Muraoka, the semantic values expressed in the simple conjugation, qal, are implied in the nuances and modalities expressed in the derived or augmented conjugations; even though the other binyanim can adopt different semantic connotations, such semantic mutations do not necessarily imply that the meaning of the Grundstamm completely disappears from the other conjugations. This elucidation is therefore limited to the study of the lexeme אמן as an exploratory way to re-discover the semantic value of its qal connotations that can serve as a hermeneutical key to re-interpret the traditional translations manifested in nifal and hifil without denying their particular semantic notions of faith and trust. ${ }^{22}$

\footnotetext{
${ }^{17}$ Joüon and Muraoka, A Grammar of Biblical Hebrew, I, 124, No. 40a.

${ }^{18}$ Ibid.

${ }^{19}$ Ibid, I, 149, No. 51a.

${ }^{20}$ Ibid, I, 160, No. 54a.

${ }^{21}$ Arnold and Choi, $A$ Guide to Biblical Hebrew Syntax, 49.

${ }^{22}$ For example, the verb platform throughout its different binyanim, meaning "to be secure, to be trusted (nifal), to make secure (piel), to cause to trust (bifil)". This means that the basic idea of its qal connotation indicates the idea of "to feel secure", which implies the reason of security, i. e., "to rely on something or someone". Even though this verb is part of the semantic map of faith in the Old Testament, it is never translated as "to

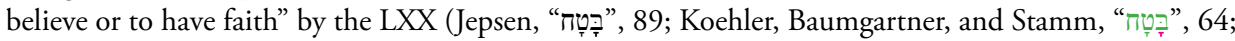
Eichrodt, Theology of the Old Testament, II, 268-90). There are other verbal examples in which the basic qal meaning may not explicitly appear in the other binyanim. The fact that a lexeme does not consistently present its basic qal meaning throughout its other conjugations, does not categorically eliminate the hermeneutical notion that the basic or primeval meaning could illumine the semantic mutations of the root in its different conjugations.
} 
Consequently, it is possible to affirm that in the case of the root the basic notions remain as a semantic substratum under which the variety of nuances utilized by the Semitic authors describe the broad spectrum of his or her religious and cultural experiences. It is for this reason that it is essential to reconsider the significance of אמָמ in its qal conjugation as a manner to rediscover its primordial meaning.

\section{The verbal form of the lexeme in qal}

The verb אָמֵ in its qal conjugation appears only in active participle in feminine as well as in masculine. ${ }^{23}$ Each time that the verb appears in its simple active conjugation (qal) it is incorporated into a paternal or maternal context. Generally, the term is employed in the Masoretic Text to describe men and women in charge of the care of babies, children, or dependent beings. The verb in its simplest form (qal) can also be translated as to nourish, to nurture, to feed, to sustain, to cover, to protect, to care, to keep safe and secure.

However, the Masoretic Text exclusively presents the verb אָּ in participle qal conveying the meaning of "nurse, custodian, or protector" of a baby or infant as it can

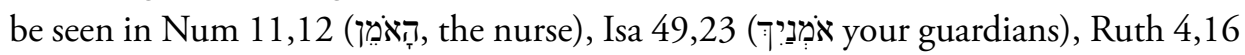

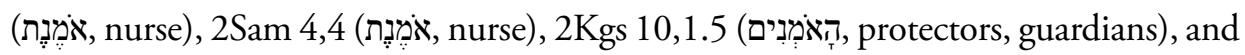
Esther 2,7 (אמ̣, foster father/protector). ${ }^{24}$ This means that the verb used in masculine and feminine throughout pericopes traditionally placed before, during, and after the Babylonian exile, signifies the proper care and concern by a father, mother, guardian, or nurse who have the responsibility of protecting and shielding children precisely because they are vulnerable and weak creatures, incapable of self-sustaining. This pragmatic notion becomes the essential premise for cognitive linguistics which ascertains that "meaning is grounded in the shared human experience of bodily existence. Human bodies give us an experimental basis for understanding a wealth of concepts". ${ }^{25}$

${ }^{23}$ Feminine participle: 2 Sam 4,4; Ruth 4,16. Masculine participle: Num 11,12; 2 Kgs 10,1.5; Esther 2,7; Isa 49,23.

${ }^{24}$ Brown, Driver, and Briggs, "אמָּ", 52.

${ }^{25}$ Janda, "Cognitive Linguistics in the Year 2015", 134. Janda uses the example of the basic experiences of babies who began to understand the notion of in and out by putting an object in and out of their mouth. In the same way the sacred authors used the basic existential experience of protection, nourishment, care, and sustenance as the embodied cognitive experience that functions as the point of reference to describe other cognitive notions, like faith, belief, trust, and faithfulness. Evans and Green, when describing the cognitive grammar constructions, especially the verbal constructions, affirm: “...if a unit is phonologically dependent it is likely to be semantically dependent as well, and if it is phonologically autonomous, it is also likely to be semantically autonomous" (Evans and Green, Cognitive Linguistics. An Introduction, 591). The obvious phonological relationship between the binyanim of אמן implies a semantic dependence; therefore, it is logical to assume the semantic notion of qal in the other conjugations of the same root. 
The text of Num $11,12^{26}$, for example, describes the supplication of Moses to $\mathrm{YHWH}$, which reflects an intimate maternal relationship. The episode shows the people of Israel as a burden, like capricious children and whimsical infants, offering the rhetorical questions of "Did I conceive all these people? Did I give them birth?" 27 on the lips of Moses. The reader can then add another rhetorical question implicit in the argumentation of Moses: Who is the mother? Certainly, it is not Moses but YHWH himself. Even though Moses is the leader of Israel, he is not responsible for the maternal nourishment and care of the people. ${ }^{28}$ Only YHWH is the one who has

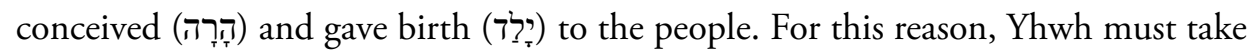

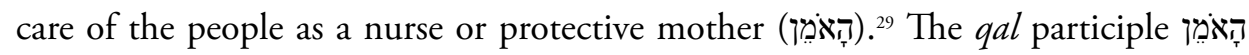
used is in masculine, but its semantic value that is determined by the context, is what expresses the behavioral pattern of a mother. ${ }^{30}$

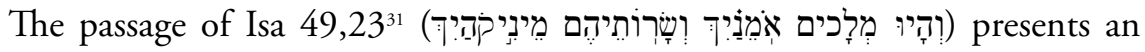

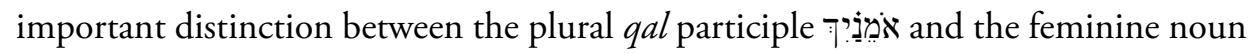
מִינֶקֶ. The Deutero-Isaian oracle presents the role of the kings as the guardiansprotectors while the princesses will become the wet-nurses, namely, those who breastfeed the infants. The passage of Isa 49,23 is part of the pericope of Isa 49,14-26. The theological content of the prophetic text expresses family relations through maternal vocabulary, as it can be seen in expressions like "can a woman forget her sucking child?

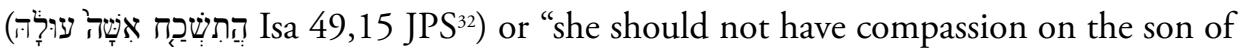

\footnotetext{
${ }^{26}$ Num 11,12 had its final textual form in the post-exile as a result of priestly writers, but the text reflects a J tradition that can be dated circa 8th century BCE (Knierim and Coats, Numbers, IV, 25; 142).

${ }^{27}$ The biblical citations are taken from the New Jerusalem Bible (New York, NY: Doubleday Press, 1985). Citations from other editions will be properly indicated.
}

${ }^{28}$ Seebass, Numeri. Biblischer Kommentar Altes Testament, 49-50; Noth, Numbers, 86.

${ }^{29}$ The maternal image used to describe the relationship of YHWH with his people is rare in the Old Testament. The following texts of the prophet Isaiah convey the maternal dimension of YHWH in the MT: Isa 49,15; 66,13. There are also metaphors that describe the motherly attitude of YHWH with Israel through the literary image of an eagle and her chicks, e.g., Ex 19,4; Deut 32,11.

${ }^{30}$ Noth, Numbers, 87. Aleksander Gomola presents conceptual integration metaphors or blend regarding the cognitive notion of God as the Father that integrates the basic notions of the participle qal but without making any allusion to the Hebrew texts presented in this current essay. One of the problematic points made by the author is the maleness implied in the linguistic metaphor of "father" and thus the author analyzes the blended metaphors of God as a "mother" (Gomola, "From God is a Father to God is a Friend. Conceptual Integration in Metaphors for God in Christian Discourse", 388-397).

${ }^{31}$ The pericope of Isa 49,14-26 belongs to the section of the Deutero-Isaiah (chapters 40-55). This section of the book can be placed during and at the end of the Babylonian Empire, namely, the latter part of the exile ca. $550 \mathrm{BCE}$ and the beginning of the return to Jerusalem ca. $535 \mathrm{BCE}$ (Thompson, Isaiah 40-66, xvii; Oswalt, The Book of Isaiah. Chapters 40-66, 3-5).

32 JPS: Jewish Publication Society of Holy Scriptures (1917). Electronic text Copyright (C) 1995-1998 by Larry Nelson (Cathedral City, CA, 92235). 


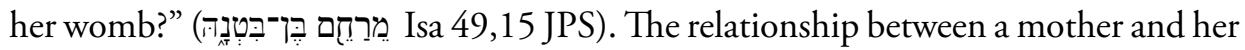
child becomes the metaphor to express the profound bond of YHWH with his people. ${ }^{33}$ The prophetic poem presents the figure of a mother (Sion) who is unprotected and abandoned. In her despair, she invoked YHWH (Isa 49,14) who replies as a empathic mother who cannot forget and abandon her own children (Isa 49,15). The oracle's divine answer is developed through images of care, nourishment, and restoration corresponding to that of a maternal love that radically changed the humiliating situation of the exiles. After experiencing the destruction of Jerusalem and the people of Israel are forced to leave their land, Isa 49,23 describes their drastic transformation through their exile. The peripeteia of the event is described by the adoption of the kings of the nations who become their guardians and protectors (qal

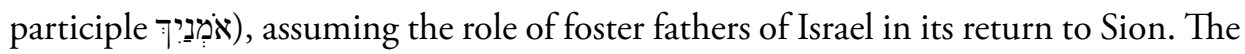
highpoint of the peripeteia is the moment when the foreign kings prostrate in front of Israel, symbolizing their humiliation and servitude. ${ }^{34}$

The verb אָָ in qal, used in feminine or masculine participle, also signifies the notion of a leader, mentor, and educator of a child or youth who embraces the role of a father and a mother simultaneously. The reader can observe this meaningful connotation in the behavioral pattern of Mordecai. He adopted the orphan Esther as

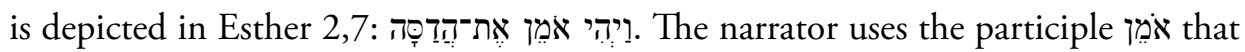
can be translated as foster father/protector or "the one who brings up." The term describes Mordecai, in this particular context, with the characteristics of a paternal pedagogue who also exercises the cares of a mother. ${ }^{35}$ When Mordecai becomes the foster father of Esther, he also assumes the double responsibility of parental protection and didactic formation of the child.

\footnotetext{
${ }^{33}$ The general structure of the pericope presents six parts: (1) The lament of Sion (v. 14); (2) the divine confirmation given in a form of a rhetorical question (v.15: see also Isa 40,27-28); (3) the promise of the reconstruction of the city: Jerusalem (vv.16-17); (4) the re-population of the city (vv. 18-21); (5) the return of the people from the diaspora (vv. 22-23); and (6) the proclamation of the divine protection. See Blenkinsopp, Isaiah 40-55, 309-310. Westermann divides the pericope in three sections: (1) vv. 14-20; (2) 21-23; and (3) 24-26. He uses the criteria of dispute and proclamation of salvation manifested in the poem (Westermann, Isaiah 40-66. A Commentary, 218).

${ }^{34}$ Wilson, The Nations in Deutero-Isaiah. A Study on Composition and Structure, 282-284; 286-287; Westermann, Isaiah 40-66, 220-221; Thompson, Isaiah 40-66, 83-84; Oswalt, The Book of Isaiah, 311-312.

35 Jepsen, "אמָמָ", 294; Levenson, Esther. A Commentary, 58; Beal, Esther, 27. See also the Note 4 of the same page. Gerleman disputes the proposal of the root II of Koehler, Baumgartner, and Albright when he analyzes the participle אמ̣p in Est 2,7. Gerleman concludes that the participle embraces all the semantic notions of the proper care and nourishment by a father and mother concurrently expressed in the Hebrew root I (Gerleman, Esther, 78).
} 
For this reason Gesenius suggests that the Greek $\pi \alpha 1 \delta \alpha \gamma \omega \gamma$ ó $\varsigma$ is the most appropriate term to translate in $_{\text {in }}$ this context. ${ }^{36}$ This episode is a good example towards the end of Babylonian exile ${ }^{37}$ where the objective semantic level of paternal and maternal care-protection acquires a nuanced meaning of education and formation. ${ }^{38}$ The semantics of qal evolves in its renditions throughout the nuanced notions derived from its basic meaning or basic experiential domain.

In the passage of Esther 2,20, the narrator affirms that Esther followed Mordecai's instructions while she was under his "care" (אָמָָָָּ). The feminine Hebrew noun אָמְָּ describes Mordecai's nourishment and education. Generally, this term can also be translated as care, tutelage, guidance, custody, oversight, and protection. All these semantic implications are simultaneously implied in this Hebrew noun, which derives from the qal of the root אמן and embodies the same semantic value of the qal participle used in Esther 2,7 (אמִן)..$^{39}$

Another example of the usage of the verb in qal expresses the basic care and custody that one may offer to a child: "Jehu sent to Samaria, to the authorities of the city, to the elders and to the guardians (דָאמקמְנים) of Ahab's children" (2Kgs 10,1).40 Jehu's intention is to exterminate the royal lineage of Ahab and accordingly he sent instructive letters to three groups of characters: the leaders and the elders who represent the authority, and the guardians (protectors-tutors: האטמנִים) who are the inner and most intimate group of the royal family. They protect and raise the future bloodline, acting as foster-parents (parental dimension) and paidagogoi (didactic dimension). The אְִָּנִים should guard and educate the princes with the attention and discipline implied in the future royal responsibilities of a monarch. ${ }^{41}$

${ }^{36}$ Gesenius, "אֵַָׁ", 58-59.

${ }^{37}$ The recent studies of Albert Friedberg and Vincent DeCaen state that the book was composed of or manifests stages of composition at some point during the end of the Babylonian exile and on towards the beginning of the Persian period. They affirm the book took its final form during the fifth century. Friedberg and DeCaen, "Dating the Composition of the Book of Esther. A Response to Larsson", 427-428. Reid argues that the book probably began to be written in the fifth century BCE, without negating the probability that its final form was established between the third and the second century BCE (Reid, Esther. An Introduction and Commentary, 21-22).

38 "Significatio fundamentalis istorum terminorum videtur ese illa sustentandi, portandi, inde fit significatio translata educandi, curam habendi" (Alfaro, "Fides in terminologia biblica", 463-464).

${ }^{39}$ Jepsen, "אָמֵַ", 294; Gerleman, Esther, 83.

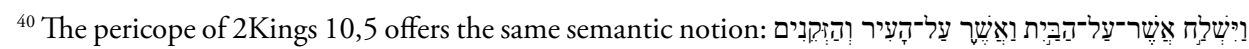

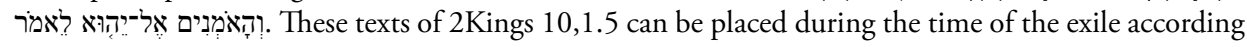
to the opinion of Noth and Veijola (Campbell and O'Brien, Unfolding the Deuteronomistic History, 426).

${ }^{41}$ Gray, I-II Kings. A Commentary, 553-554. 
The passage of Ruth 4,16 maintains the same semantic line. ${ }^{42}$ The verse says: “... and Naomi, taking the child, held him to her breast; and it was she who looked

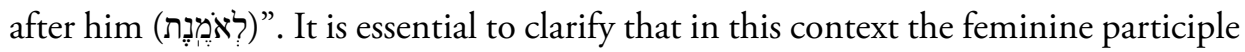
אמקמָנת does not signify a wet-nurse or a nurse who feeds with her breast milk. Naomi's age would not allow it, and for this kind of function the author would use the more

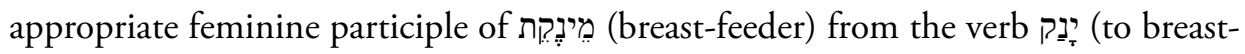
feed). It would be erroneous to deduce that the latter verb is a synonym of according to the similarity of maternal contexts. Naomi assumes the responsibility of raising a child according to a maternal and pedagogical dimension. ${ }^{43}$

Following the semantic line of the qal conjugation manifested in the aforementioned texts, one can deduce that the primordial meaning of the verb אָ is is "to take care and guide responsibly," ${ }_{44}$ or "to protect, to nurture, and to educate." ${ }^{45}$ Therefore, the most primeval semantic level of wָ in qal is not identical with the meanings expressed in nifal and hifil because "in forma qal non apparet significatio credendi" 46. Therefore, the nifal and hifil assumed and evolved theological and cognitive meanings are built from the basic meaning expressed in qal. Using the terminology of cognitive semantics, the embodied notions of qal become the point of reference to construe the ontological metaphors of faith, trust, and belief implied in the nifal and hifl. ${ }^{47}$

The qal conjugation, being the simplest in the Hebrew verbal system, has the value of being the most basic conjugation in comparison with other binyanim. This implies that qal expresses the most fundamental semantic value of the Hebrew root אמן. This statement is found in the philological studies and analysis of Paul Joüon and Takamitsu Muraoka. The other conjugations, like nifal and hifil, derive from the most basic verbal conjugation of qal by way of augmentatives forms through the additions or changes of prefixal and suffixal elements, acquiring different nuances and

\footnotetext{
${ }^{42}$ Most of the academic opinions place the book of Ruth between the exile and post exile, namely between the end of the Babylonian and Persian dominions. McKeown deals with the puzzle of the dating of the book of Ruth, indicating that are not conclusive the literary evidence of the book, since it presents archaism that denote a pre-exilic period and Aramaisms that reveal a Persian period (McKeown, Ruth, 2-4). ${ }^{43}$ Sasson, Ruth. A New Translation with a Philological Commentary and a Formalist-Folklorist Interpretation, 172.

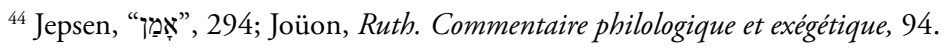

${ }^{45}$ Mandelkern, Veteris Testamenti Concordantiae Hebraicae atque Chaldaicae I, 108.

${ }^{46}$ Alfaro, "Fides in terminologia biblica", 464.

${ }^{47}$ Janda, “Cognitive Linguistics in the Year 2015”, 140-141; Lakoff and Johnson, Metaphors We Live By, 31; Evans and Green, Cognitive Linguistics, 294-295.
} 
modalities of meaning built upon the basic semantic value expressed in qal. ${ }^{48} \mathrm{On}$ this matter, Joüon and Muraoka affirm in the following statement:

The Hebrew verb comprises a number of conjugations: a simple conjugation, called qal (light) and a number of derived or augmented conjugations. The simple conjugation is well named because, in comparison with the others, its form is the simplest and the action which it expresses is equally simple [...]. The derived or augmented conjugations have an expanded form in relation to the simple conjugation, and the action which they express has an added objective modality. ${ }^{4}$

The nuances that are usually translated as to trust, to believe, to be faithful, certain, reliable, stability, etc., are embraced in the nifal and hifil forms together with the substantive forms of the same root, but the basic spectrum of semantic notions flourish from the primary notion expressed in qal. This means that one may trust and believe in somebody else because he or she protects, cares, guides, and behaves as a mother or a father. The notions of security, trust, stability, and fidelity become manifestations of the fundamental act of a parental love and care that cannot reject or abandon its children. ${ }^{50}$

\section{Portraying the verbal form of in nifal through the semantic notion of qal}

The nifal conjugation of אָמֵ expresses the reflexive or passive dimensions of the simplest action or verbal conjugation which is qal. ${ }^{51}$ The binyan nifal of predominantly appears in the Masoretic Text in participle: approximately 32 times, with five presences in the perfect tense, and eight recurrences in the imperfect. ${ }^{52}$

The text of Isaiah 60,4 encompasses an important significance for the present study. The verb is used in a passive or reflexive form, having the same semantic value of qal. This is one instance in which it is evident to perceive the same basic meaning of qal in the nifal. The verb has the maternal connotations of a person who is taking care of children: "Lift up your eyes and look around: all are assembling and coming towards you, your sons coming from far away and your daughters being

\footnotetext{
${ }^{48}$ Joüon and Muraoka, A Grammar of Biblical Hebrew I, Nn. 51, 54.

${ }^{49}$ Ibid., I, 124, No. 40a.

${ }^{50}$ See part of this academic debate regarding the basic meaning of the root אמן in Wildberger, "ן",", 136; Idem, "Glauben im AT", 129-159.

${ }^{51}$ Joüon and Muraoka, A Grammar of Biblical Hebrew I, No. 51a.

52 Jepsen, "אֵַָׁ", 294. In his statistic data Jepsen omits the pericopes of Hos 5,9; 12,1 and 1Cro 17,24.

The reason of the omission is the corrupted and obscure state of the Hebrew texts.
} 


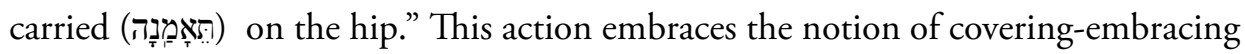
the baby with extreme care, i.e., being very close to the person's body. The purpose of the statement describes the care in bringing the children to his or her mother.

It is important to highlight the semantic field of parental protection in nifal because it is not often mentioned in the philological analysis of specialized lexicons as the ones aforementioned. The reason for this tendency is the emphasis made on the predominant semantic connotations of "to believe, to trust, or to be faithful." Thus the pericope of Isa 60,4-9, describes Zion glorified by a people who will be accepted as the Lord's worshippers ${ }^{53}$, portraying the basic qal connotation manifested in nifal in a post-exilic literature. ${ }^{54}$ The Trito-Isaiah (chapters 56-66) expresses a more universal and inclusive theological reflection due to the circumstances of the people of Israel who have been facing problems of faith after experiencing their exile..$^{55}$

The paternal and maternal notions, however, remain as the basic semantic substratum which expresses the primary meaning of the verb, which is the action of covering, taking care, and protecting. This typical parental attitude toward an innocent creature resides as the basic platform of the action to believe at its primeval semantic notion. This semantic cross-domain mapping is the cognitive process of creating an ontological metaphor in which one takes a concept formed from a human parental experience (personal physical space) serving as a source domain for metaphors of faith and trust which are the abstractions or conceptualization of theological notions to develop. ${ }^{56}$ One person has faith or may come to believe in another person because one has the experience that the other is reliable, firm, secure, and faithful. From that experience one has the certainty that the other person will protect and guide the one who is defenseless.

Keeping in mind this connotation, the reader can then apply the same semantic nuance of the studied verb to a theological field in which the people of Israel have similar experiences with God. This means that Israel believes (meaning in nifal and hifil) in God because Israel already knows through its own history that YHWH has

\footnotetext{
${ }^{53}$ Motyer, Isaiah. An Introduction and Commentary, 420-421.

${ }^{54}$ Blenkinsopp, Isaiah 56-66, 59; Niskanen, Isaiah 56-66, xi-xii, especially notes 8-9; Von Rad, Teologia dell'Antico Testamento Vol 2. Teologia delle tradizioni profetiche d'Israele, 326-329; Thompson, Isaiah 40-66, xxix-xxx; Oswalt, The Book of Isaiah, 3-6.

${ }^{55}$ Von Rad, Teologia dell'Antico Testamento 2, 328. During this life setting, the Trito-Isaiah uses the basic objective meaning (parental care) of last during the Babylonian and Persian periods (Niskanen, Isaiah 56-66, xii-xiii).

${ }^{56}$ Janda, "Cognitive Linguistics in the Year 2015”, 140-141; Lakoff, "Conceptual Metaphor. Contemporary Theory of Mataphor”, 185-186; 232-233.
} 
protected them like a mother and father (meaning in qal). The relationship that exists between God and Israel manifests the same dynamics of a familial relationship between parents and children at its more basic core values. For this reason it would be a mistake to omit or reject the analysis of these basic semantic connotations of qal manifested in the other conjugations. ${ }^{57}$

The term נֶמָמן (nifal) embraces a variety of meanings that generally can be translated into English using the terminology of being firm, being secure, to be trusted, and to be faithful. From these verbal forms other adjectives and substantives derive, e.g., "secure, stable, faithful, belief, security, trust, and fidelity." For this reason, Moberly identifies the semantic connotations of (nifal) as synonymous to 'emet $y$ 'emûna . $^{58}$ When the lexeme is applied to a very specific person in the Old Testament, the indicated personage manifests the same characteristics of security and stability immersed in a dimension of fidelity. ${ }^{59}$

The verb often is translated as "to be faithful", which has become the stereotypical meaning of this verb in nifal, as one can see in the pericope of 1Sam 22,14"0: "...of

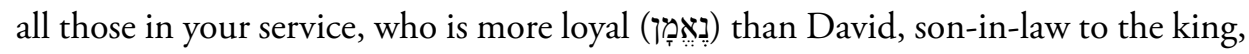
captain of your bodyguard, honoured in your household?"”. The pericope of 1 Samuel has a double implication. One is the presentation of David as a person who has high qualities, namely, David as being incomparable and superior to all the servants of King Saul, because he possesses like no other the quality of The second implication expresses a judicial argument on behalf of David who is not regarded in high esteem by King Saul. In both cases the term נֶמָמָן embraces the dimension of innocence and fidelity together with the intention of exultation of the personage. ${ }^{61}$

The verb in nifal usually appears in judicial contexts in which it is necessary to have the participation of truthful and reliable witnesses. This means that the moral quality implied in the verb guarantees the certainty of the truth manifested by those who exemplify this characterization. This connotation is significant because the root

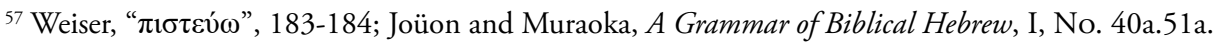

${ }^{58}$ Moberly, "אמן", 431; Wildberger, "אָמֵן", 138.

59 Jepsen, "אמֵָ" 295.

${ }^{60}$ The text of 1Sam 22,14 is placed during the exile by Noth and Smend, but Frank Moore Cross places it during the time of the Monarchy of king Josiah, circa the seventh century (Campbell and O'Brien, Unfolding the Deuteronomistic History, 12-13.269-270; Cross, Canaanite Myth and Hebrew Epic, 278-285; Tsumura, The First Book of Samuel, 11-19.

${ }^{61}$ Ibid., 545; Mabee, "Judicial Instrumentality in the Ahimelech Story", 29. See also Note 30 of the same page. Other examples of that present the same semantic notion are Num 12,7; Prov 11,13; 25,13; 27,6; Neh 13,13; 1Sam 22,14; Psalm 101,6; Job 12,20. These pericopes denote historical contexts that span from the exile and post exile, namely, from the Babylonian and Persian periods.
} 
אמן is closely interconnected with the notion of truth. The Hebrew noun employed to signify the idea of truth is wמכת which is precisely derived from the root Consequently the substantive which belongs to the same philological field (Wortfeld) of the root can be translated as firmness, security, trust, stability, and solidity. ${ }^{62}$

The same semantic spectrum, when applied to God, acquires a richer value by way of analogy. When God becomes the subject of the verb, multiple semantic levels interplay simultaneously in the narrative, so that the term expresses a rich polysemy that cannot be adequately articulated in any other translation. Hence, modern translations only offer or reflect one single dimension of the polysemy. In the Masoretic Text, the person of YHWH is essentially described with the notion of that that can be translated as faithful and constant (נָאמדן). The nature of the Lord is secure, stable, reliable, and truthful. Those are essential qualities of his essence and for this reason Israel can trust in him because his nature is to be נִ. ${ }^{63}$

The nifal participle with this specific theological connotation appears very few times in the Masoretic Text describing the nature of YHWH. The three most important passages in which the term appears describing the natura Dei are Deut 7,9; Isa 49,7, and Jer 42,5. ${ }^{64}$

The Deuteronomistic theology does not admit any flaws in the representation of YHWH in its narratives. ${ }^{65}$ For the Deuteronomistic author, the essence of YHWH is

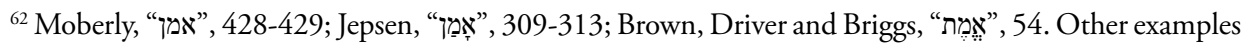

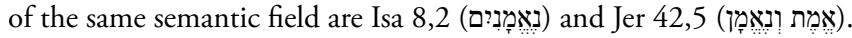

${ }^{63}$ Jepsen, "אָמָן", 295-296.

${ }^{64}$ The text of Isa 49 can be placed at the end of the Babylonian exile and the beginning of the Persian dominion (Stuhlmuller, "Deutero-Isaiah and Trito-Isaiah", 330). Regarding the book of Deuteronomy, the first speech of Moses (Deut 1,1-4,40) reflects eighth to seventh century material, the second speech (Deut 5-26) reflects the time of the Judean monarchy during the Persian Period and the Josianic reform of the seventh century BCE, and the third speech (Deut 29,2-32,47) reflects the exilic community during the Babylonian period, after the destruction of Jerusalem. Even though the material is archaic the final form of the book was established during the end of the exile (Brueggermann, Deuteronomy, 18-20; Lundbom, Deuteronomy. A Commentary, 6-14). The oracles of Jeremiah began to be collected at the end of the seventh century and the first half of the sixth century, but the final form of the book can be dated approximately at the end of the Babylonian exile or soon after it (Sharp, Prophecy and Ideology in Jeremiah. Struggles for Authority in the Deutero-Jeremianic Prose, 1-7).

${ }^{65}$ Von Rad, Teologia dell'Antico Testamento 1, 259; 265-266; 379-382. The hagiographers of the Deuteronomistic history had created a theological opus based on the careful selection of literary material in order to present a theological exposition of the History of Israel determined by the invariable faithfulness of YHWH and the disloyalty of his people. See Childs, Introduction to the Old Testament as Scripture, 236-237; Campbell and O'Brien, Unfolding the Deuteronomistic History, 20-22; Richter, "Deuteronomistic History", 222-223.
} 
nurturing, and security. Therefore, any manifestations of the connotations embraced in the Wortfeld of אָָ have their own origin and supreme manifestations in YHWH himself. This also means that all the manifestations of the verb jugations - express and describe the essence of YHWH. All of YHWH's personal revelations through the Old Testament narratives essentially define the notion of faith which implies fidelity, security, trust, protection, and truth because all of them come from the paternal and maternal love of YHWH who never abandons his own children. The pericope of Deut 7,9 embraces these theological notions. ${ }^{66}$

The text describes this essential detail of YHWH's nature that is interconnected with his being נֶֶָמָ in the performance of his covenant. This fundamental characteristic expressed with the notion of gentleness, and affection that also connotes stability and love. According to this divine love (חֶ), God chooses Israel not because of the merits and high moral standards of the people but because his choice comes from his pure divine initiative. The divine selection, then, is based on his ח्ֶ? and divine promise offered to Israel's ancestors (see Deut 7,7-8). The experience of security by Israel is pragmatic in the person of God who always manifests himself through concrete deeds done throughout Israel's history, revealing a relationship of constant love and interaction with his people. This choice implies the proper responsibilities and obligations through an exclusive relationship, in which every single party must keep himself faithful to the stipulations implied in the covenant. ${ }^{67}$

For this reason, the obedience of Israel to the divine law (Torah and mitzvoth) becomes the concrete and existential dimension in which the communion with God is experienced and established. The great faults and unfaithfulness of Israel towards YHWH provoked his righteous retribution because God is always faithful. Therefore, he has to punish his children as a paidagogos has to discipline the children under his care. His didactic behavior does not come out of rage but out of love so Israel can learn from its own mistakes. In this manner YHWH continues to manifest his fidelity and goodness towards those who come to establish a personal relationship of love with him.

The book of the prophet Isaiah also applies the same semantic connotation when the sacred author talks about the fidelity of YHWH towards the one who has been rejected and marginalized. The figure of the servant of the $\operatorname{Lord}^{68}$ embodies this

\footnotetext{
${ }^{66}$ Wildberger, "אמן", 139.

${ }^{67}$ Nelson, Deuteronomy, 100-102.

${ }^{68}$ Wildberger, "אמן", 139. The pericope in which this verse is inserted is Isa 49,7-13. The text corresponds to two epexegetical comments to the canticle of the servant of YHWH in Is 49,1-6. The first epexegetical comment is given by verse 7; the second is expressed in the verses 8-12. The pericope concludes with a hymnal stanza in verse 13 . See Blenkinsopp, Isaiah 40-55, 304.
} 
theological connotation in the book of the Deutero-Isaiah: "YHWH who is faithful

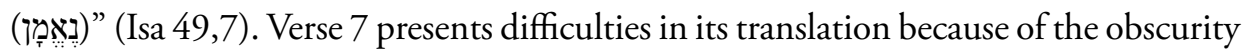
of the verbal forms in the manuscripts of better textual tradition. ${ }^{69}$ The Hebrew verse can be structured in two main parts. The first part is the voice of the narrator that introduces the divine utterance $(7 \mathrm{a})$. The second part is the divine proclamation addressed to the person that is known in the tradition as the servant of YHWH (7b). The thematic and theological content of the verse seems a paraphrase of the fourth canticle of the servant of the Lord in Isa 52,13-15. ${ }^{70}$

The verse follows the same narrative and theological pattern of humiliation of the servant who ultimately would be acknowledged by all the kings and exalted

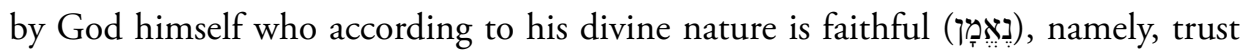
worthy because he did not abandon his servant. Verse 8 of the same chapter offers a theological explanation of the behavior of God described already with the term in $49,7 \mathrm{~b}$. Therefore, Verse 8 is an epexegetical description of what it truly means to be faithful (נְֵֵמן) according to the nature of YHWH. This elucidation is not based upon theoretical and abstract notions but on the tangible experiences of the existential reality of the person who is suffering, namely the servant. That is why Verse 8 in its description talks about the answer of God, the salvation, the help, and the restoration of the one who was previously rejected and marginalized. ${ }^{71}$ The divine intervention has the peripeteic purpose. YHWH transforms the situation of the suffering servant so he can become an instrument of restoration for the people.

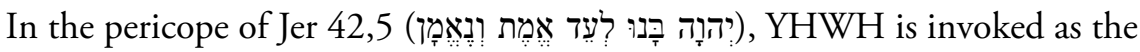
truthful and faithful witness. The qualification of his nature is expressed by the sacred author as if God would be the only person to have the absolute essence of the attributes

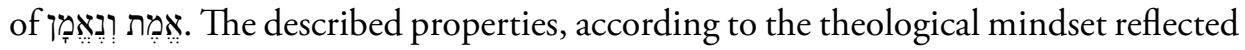
in the book of Jeremiah, are fundamental qualities of the natura divina Dei. Hence,

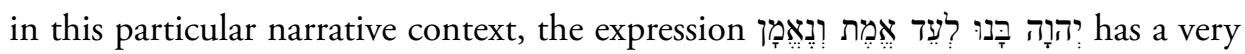
exclusive characteristic because no human being can possess in an absolute manner the attributes of אמֶֶת וְנָאמָן his or her ontological nature. ${ }^{72}$

${ }^{69}$ Childs, Isaiah, 386.

${ }^{70}$ Ibid.; Blenkinsopp, Isaiah 40-55, 349.

71 "Thus says YHWH: At the time of my favour I have answered you, on the day of salvation I have helped you. I have formed you and have appointed you to be the covenant for a people, to restore the land, to return ravaged properties" (Is 49,8 NJB).


They request the intercession of Jeremiah in front of YHWH. the verse 5 expresses a solemn oath that states the true nature of YHWH and the trust that the people have placed in him. The function of the 


\section{Portraying the verbal form of אמן in hifil through the semantic view of qal}

The causative conjugation called hifits ${ }^{3}$ predominates in the Wortfeld of the root אמן. The hifil form of the verb appears 52 times, expressing the meaning of security and stability that commonly is translated as "to trust". The LXX translates the verb 45 times, out of the 52 presences in the Masoretic Text, with the verb

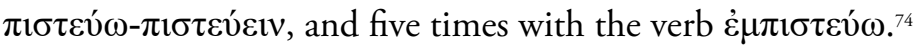

The hifil of implies the semantic idea of "to say amen with conviction to all its implied existential consequences". ${ }^{75}$ This means that the verbal connotation implies the acknowledgment that the person who speaks or the object of the conversationaffirmation are considered secure, stable, and reliable, meaning that they are true since there is no doubt that they do not exist. The most common translation for this verbal conjugation is "to believe" or "to trust" because these English verbs embrace the acceptance and acknowledgment that the other person (or object) is authentic and infallible. ${ }^{76}$ But is it possible to discover the basic meaning of qal in the theological connotation of ș in hifl? My proposal continues to be a positive respond.

Regarding this query, Walther Eichrodt presents a significant observation that states that the hifil הֶמֵמ can be properly translated as "to consider firm, trustworthy, to find to be reliable" as way to positively describe the relationship with God. But he also affirms that "since the basic meaning of the root $m n$ in Arabic is to be secure, out of danger, one could choose as the preferable translation of the Hebrew he'emin,

oath pretends to convince Jeremiah that the people's intention is sincere. See Lundbom, Jeremiah 37-52. A New Translation with Introduction and Commentary, 128-129.131.

${ }^{73}$ Joüon and Muraoka, A Grammar of Biblical Hebrew I, No. 54a.

${ }^{74}$ The LXX predominantly translates the hifil form of the verb אָָ with the verb $\pi \iota \sigma \tau \varepsilon v i \omega$, that often is rendered in English with the verb "to believe" (see Gen 45,26; $1 \mathrm{Kgs} \mathrm{10,7),} \mathrm{"to} \mathrm{trust,"} \mathrm{and} \mathrm{"to} \mathrm{obey."} \mathrm{But}$ these possible translations of the Hebrew word cannot totally embrace all the semantic levels implied in the Hebrew root of אמן. The Greek translation already filters through the Western experience and culture as a rich spectrum of nuances embodied in the Hebrew term. The cultural change manifested in the language establishes also a new semantic context of expression. In Greek, the notion of the lemma $\pi \iota \sigma \tau \varepsilon v ́ \omega$ emphasizes more a noumenal dimension—cognitive or intellectual process—of the action of believing, as it is found especially in the classic Hellenistic literature. One may do the semantic connections with other vital aspects embodied in the personal or communal relationship signified with wָ especially the notion of trusting $(1$ Sam 27,12$)$. However, the semantic ramifications connected and discovered by a reader are not enough for the Greek verb to embrace the vast spectrum of vital nuances and meanings embraced in the Hebrew root. Consequently, the phenomenon of faith expressed with אמָ is richer than

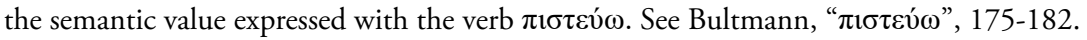

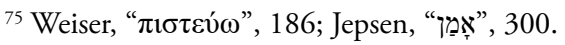

${ }^{76}$ Wildberger, "אמן", 142. 
to regard as assured, to find security in". ${ }^{77}$ Eichrodt recognizes the semantic notion of qal implied in the hifl form but through its Arabic parallel, indicating that the bifil of "to trust and to believe" implies the notion of protection, care, and security expressed in qal.

An illustrative example of this semantic line is offered in the pericope of Exod 4,1-9. ${ }^{78}$ The episode describes different signs given by YHWH in order to confirm the authority of Moses ahead of Israel. The recurring use of the root in hifil is very

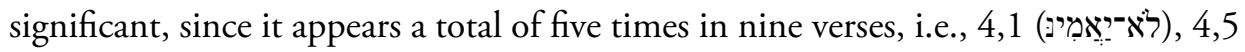

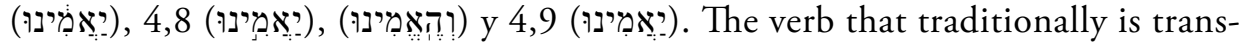
lated as "to trust," embraces a more complex theological and social connotation because it expresses a notion that goes beyond the simple act of accepting Moses as a leader. The lexeme conveys the certainty that the leader is trustworthy because God himself has chosen him and has approved his appointment through visible signs. The semeia communicate a phenomenological dimension that leads Israel to the cognition and conviction that YHWH is acting through his leader, Moses. ${ }^{79}$

The usage of (bifil), applied in a human context, signifies the basic attitude of total trust in which the action of believing is strictly intertwined with the act of

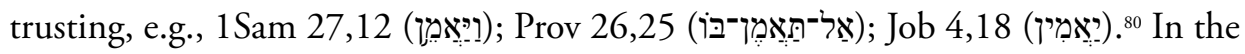
moments in which a person addresses God using the verb אמָ in hifil form, then such information simultaneously expresses a declaration that God, according to his own nature, is essentially נִאטָמן. In other words, it would be the equivalent of professing an "amen" to whatever God is and commands with all the ontological implications

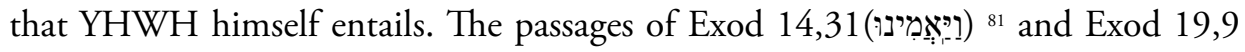
(יאמינמנ:

77 Eichrodt, Theology of the Old Testament, II, 276; Jepsen, "אַָָׁ", 298.

${ }^{78}$ The book of Exodus reflects material and layers of composition that can be dated between the ninth and eighth century BCE, but there is also material that reflects the post-exilic era, during the Persian dominion and the beginning of the second Temple era, time in which probably was established the book in its final form (Bruckner, Exodus, 8-10; Meyers, Exodus, 16-18).

${ }^{79}$ Durham, Exodus, 44-46.

${ }^{80}$ The texts of the books of Proverbs and Job indicate the use of the hifil in the Wisdom literature that predominates during the Persian period (Sneed, The Social World of the Sages. An Introduction to Israelite and Jewish Wisdom Literature, 302; 328-329).

${ }^{81}$ The verses of Exod 14,30-31 present synthetic précis of Chapter 14. In the last two verses the sacred author affirms the superiority of YHWH who overcame the Egyptian power. See Durham, Exodus, 197.

${ }^{82}$ Exod 19,9 makes reference to the advent of YHWH who demands a proper preparation where God can speak openly to Moses in a public setting. The purpose of this public setting is to ratify Moses as the unquestionable leader of the people. See Durham, Exodus, 264. 
The reader must observe that the action of believing is certified with the visible deeds (semeia) through the events described in the narrative of Exodus. ${ }^{83}$ What is the meaning of this? In the transformational process of the strengthening faith of Israel, the wonderful deeds of YHWH are the fundamental proof of his divine existence. The Old Testament describes the personal relationship of Israel with YHWH —and vice a versa - through the unfolding events of the human history that are interpreted and experienced through the eyes of the Israelite spirituality.

That faith, resulting from the historical manifestations of YHWH, becomes a certain "knowledge" (scientia) that God truly exists and acts on behalf of his people, protecting them as a father and mother simultaneously. God is consequently genuine, true, and undisputable in the theological Israelite mindset. Faith is a kind of cognition or knowledge that comes as a consequence of a personal experience of God who interacts with his own people. This assertion indicates that faith is a scientia Dei.

The Old Testament does not describe faith according to epistemological definitions of the Western philosophical mindset. Faith, in the first Testament, embraces concrete and pragmatic conceptions that came out of the experiences of God's deeds on behalf of his people. It is a phenomenological understanding of faith that implies the complete abandonment into the hands of God who is as certain and reliable as parents are for their children. ${ }^{84}$ The liberation from Egypt, for example, is a concrete proof of the firmness and veracity of YHWH. Each act of his divine salvation in the Old Testament offers a corroboration of the infallibility of YHWH. ${ }^{85}$

${ }^{83}$ The only source of salvation is YHWH and Israel has seen it (ำ? I): Exod 14,31. See Durham, Exodus, 197.

${ }^{84}$ See 2Chron 20,20: “iTrust (הַאמִמינו) in the Lord, and you shall be free!”

${ }^{85}$ The trust in God many times is narrated from a negative point of view in the sacred texts because Israel continuously disobeys God and his commandments, giving proof to their flawed trust that makes them incapable of honoring the mitzvoth of the covenant. The Israelite behavioral pattern demonstrates an essential skepticism to the divine providence, manifesting itself in sharp contrast with God's faithful deeds. The action of believing requires, then, the action of acceptance that God himself is true and operates always in favor of the one who has placed his/her trust in him. The semantic notion of faith-manifested in the hifilverbal conjugation-implies the capacity of abandonment into the divine Providence with the same confidence that young children — or a baby—rely on the care of their parents. This line of thought indicates that the notion of an existential knowledge that is not based upon abstract philosophical ideas but on the personal and real experiences of God's care that relies on the semantic notion of the parentchild relationship. The parental analogy expressed in the qal conjugation remains, therefore, as the basic semantic platform of this nuance signified in hifil. See Deut 9,23: "You rebelled against the command

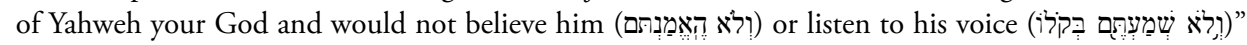

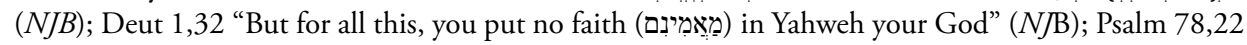

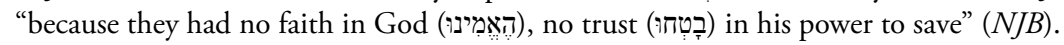


Another illustrative example of this line of thought is given by the comments of Von Rad when he analyzes the faith of Abraham, in Gen 15,6. The post-exilic text uses the verb in hifil (וְהמקט), meaning "to have faith or to believe" which is the typical connotation of אמן in hifils. However, Von Rad proposes as a more appropriate translation of this verb the meaning of "to make oneself secure in YHWH" which is a more common meaning of parental care and protection expressed in the qal conjugation. ${ }^{87}$ For this reason, the faith in the Old Testament implies the total self giving into the hands of God which is based upon the parental notion of protection, in the same way Abraham did (Gen 15,6), or a defenseless person, like a child must do in putting his or her life into the care of a protector. This also implies that whatever God utters has the certainty that it would be accomplished, according to the basic schema of divine utterance and fulfillment (e.g., Exod 4,1.31; 19,9).

The verb אָָ consequently embraces a complex personal attitude inferring the fear of the Lord, meaning that he certainly exists and is true to his nature (cfr. Isa 8,13). Because of his divine character, his relationship with the people, or with particular individuals, requires obligations and responsibilities that simultaneously are complemented with reverence, awe, trust, and obedience. Dimensions that make Israel feel secure and protected like a child in the arms of his parents. Isa 28,16 illustrates this notion further by emphasizing the imagery of a solid and firm rock that has been tested through time. ${ }^{88}$

The "historical dimension" implies the retrospective view that serves to guarantee any person who has placed his/her trust and security in YHWH that no matter what happens the faithful will not be disappointed. Through the historical proof of the past events the faithful have certainty that the same divine behavioral pattern remains constant through time, implying that the same parental activity of God will continue forward into the present time with an implicit eschatological dimension. ${ }^{89}$

Among their contextual diversities, the Psalms present magnificent phenomenological expressions of faith that are so practical and realistic that the psalmist

\footnotetext{
${ }^{86}$ Von Rad, Genesis, 184-185.

${ }^{87}$ Idem, Teologia dell'Anico Testamento 1, 203.

${ }^{88}$ The notion of the tested rock has a rich hermeneutical history manifested in the Psalms (e.g., Psalm $27,5 ; 28,1 ; 61,13)$ and the prophetic writings. The image suggest theological, spiritual, and architectural notions. See Wildberger, Isaiah 28-39, 40-41. The pericope of Isa 7,4-9 proclaims an oracle of salvation.

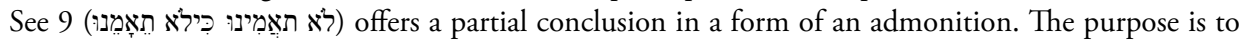
offer an invitation to trust in YHWH because he is true and secure. The oracle is proclaimed during difficult times, especially in a context of imminent war. God particularly wants in these difficult times the people to put their faith and trust in him. See Wildberger, Isaiah 1-12, 285; 289-291.
}

${ }^{89}$ Kaiser, Der Prophet Jesaja Kapitel 13-19, 201. 
has the conviction that whatever God proclaims must be accomplished and fulfilled during his own span of life. The confidence of the psalmist makes him place his faithful trust in YHWH in his present time. An illustrative sample of this theological tradition

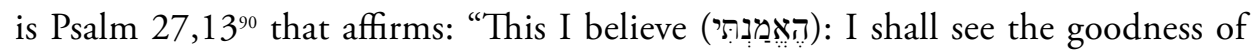
Yahweh, in the land of the living."

The psalmist utters an absolute belief in YHWH that rejects any possible scenario of accomplishment in the world to come (eschatological dimension). The fulfillment of the divine promises will not be experienced in the future generations but in the present time of the psalmist. Such unconditional certainty does not give any space for the waiting time that is beyond the present vital moment.

\section{The Faith of Israel through the semantic stratum of in qal: conclusions}

The conception of in in qal conjugation is exclusively circumscribed within a parental and familial semantic context while at the same time it is the primordial platform of meaning upon which the other conjugations and derived lemmas express their various meanings. ${ }^{91}$ The original value of the Hebrew verb in qal expresses the care, protection, nourishment, sustenance, and embracing of a parent for his/her children. Therefore, the cross-domain mapping derived from the fundamental notions implied in qal offers six primordial semantic fields as conceptual integrative lines of meanings: 1. Family relationship as the source domain semantic experience. The parents are the protectors, nurturers, educators, and guardians of the children who are defenseless and incapable of self-sustaining. The family relationship that embraces all these responsibilities is based on love. The extended notion of family also implies that the same aforesaid responsibilities are performed by the grandparents and all the members of the extended family, typical of the ancient Semitic mindset. The family bond becomes a source of identity for their members, connotation that describes the theological and spiritual relationship of YHWH with Israel manifested in the Old Testament.

2. Attitude of protection. It is motivated by the love of a mother or father for their children. The same behavior can be performed by a mentor, guardian, or nurse. The

\footnotetext{
${ }^{90}$ The Psalm 27 may reflect a pre-exilic situation as well as a time of the end of the exile and post-exile. It is impressive the wisdom character of the psalm that alludes to a post-exilic period. The Psalm 27 can be divided in two clear sections: (1) 27,1-6 which expresses the courage of faith of the psalmist in God; and (2) 27,7-14 which expresses the path that leads to God, describing the faith and conviction of the psalmist in the Lord (Weiser, The Psalms. A Commentary, 91-95.244-246.250-251; Schaefer, Psalms, 66-69).

${ }^{91}$ See 2 Sam 4,4; Ruth 4,16; Num 11,2; 2 Kgs 10,1.5; Esther 2,7.
} 
level of protection increases according to the intensity of the personal relationship. It is a semantic notion derived from the family relationship. The same semantic profile is embraced in the relationship of YHWH with Israel through the experience of the Exodus, wandering in the desert, and throughout the Babylonian exile.

3. Attitude of nourishment. It is motivated by the proper love and care of the parents. The ones responsible for raising children feel compelled to nurture them in order to sustain and preserve their lives in the best way possible. It is a semantic notion derived from the family relationship. The same notion is applied to the theological dimension of faith in Old Testament as it is illustrated in the Exodus, Numbers, Psalms, Deutero and Trito Isaiah.

4. Didactic role. It is appropriate for parents to become the paidagogoi of their children. The education guarantees the preservation of traditions and behavioral patterns that are considered to be righteous. From a theological point of view, YHWH is the paidagogos of Israel.

5. Sense of security. It is a proper response by children or young persons who come to comprehend this awareness through experiencing security and protection from the one who loves them. It is a pragmatic knowledge through repetitive experiences. Through experiences of hardships, the faithful remnant of Israel finds the courage to persevere through their trust in God. It is a semantic notion derived from the family relationship and the attitude of protection embraced in the meaning of (qal).

6. Historical proof. It is a semantic notion derived from the experience and knowledge of security and protection. Children who become adults would have a solid trust in their parents who always were committed to them. The constant and faithful attitude of protection, nourishment, and teachings of YHWH create a behavioral pattern that proves to be constant in the present and future events. It is a semantic notion derived from the semantic fields of family relationship (a) and the attitude of protection (b). The religious drama of Israel is their lack of anamnesis at the moment of remembering the deeds of YHWH on behalf of his people. However, the sacred hagiographers constantly remind the people of Israel that in the same manner how YHWH freed his people from the slavery and hardships in the past, in the same way YHWH will continue to deliver his faithful people from the hardships of the present and future. ${ }^{92}$

From a diachronic standpoint, the basic semantic notion of the root manifested in qal has evolved throughout time. The notion of qal appears in texts that according to their final form can be located from the time of the exile and post-

\footnotetext{
92 The episode of a young David illustrates this historical and theological conception of "trust" and "faith" based upon the experiences of "protection": 1 Sam 17,34-37. See Tsumura, The First Book of Samuel, 72.
} 
exile, namely, from the Babylonian and Persian periods. ${ }^{93}$ However, some of these texts may reflect a material or tradition that can be placed between the 8 th and 7 th century BCE. ${ }^{94}$

The same line of thought can be appreciated in the use of the basic meaning in its passive form (nifal) in Isa 60,4, indicating that even during the Persian period basic human experiences of parental care and protection are used in the root אמן even in nifal conjugation. Therefore, the basic semantic cognitive domain remains even though the theological and more abstract notions are being used simultaneously through the same root in nifal and hifil.

The traditional meanings expressed in nifal and hifil predominate in texts that can be placed during the time of the exile and post-exile. ${ }^{95}$ It is significant the text of Jer 42,5, because its material began to be collected between the seventh and the sixth centuries BCE, thus the ontological notion of נִ used to describe the nature of YHWH appears as early as pre-exilic times of the Babylonian period or during the transition from the Assyrian to the Babylonian period. ${ }^{96}$

If the different meanings of the same root are used at the same time, which one supposes to be the most archaic or basic meaning? From the standpoint of the cognitive linguistics, the notions of qal become the most plausible option. Cognitive linguistics assumes the principle that the basic meaning is embodied, i.e., it is grounded in the vital human experience of corporeal existence. ${ }^{77}$ The notions of parental care, protection, and nurture are the most basic bodily or corporeal experiences that any human being has since the moment of his/her birth.

This human experience serves as the experiential basis for understanding the more abstract notions of education, discipline, trust, faithfulness, faith, and belief. Therefore, the qal expresses a cognitive source domain from which the sacred authors try to implement their notions into the domain of God and the experience of the relationship existing between YHWH and Israel..$^{98}$ The basic meaning of qal remains

\footnotetext{
${ }^{93}$ Isa 49, 14-26; Esther 2,7; Ruth 4,16; Num 11,12; 2 Kgs 10,1.5.

${ }^{94}$ See the references of Num 11,2 and $2 \mathrm{Kgs} 10,1.5$.

${ }^{95}$ Examples in nifal: Isa 49,7; Deut 7,9; Jer 42,5; Num 12,7; Prov 11,13; 25,13; 27,6; Neh 13,13; 1 Sam 22,14; Psalm 101,6; Job 12,20. Examples in hifil: Exod 4,1-9; 14,31; 19,9; Gen 15,6; Isa 28,16; Psalm 27,13; 1Sam 27,12; Prov 26,25; Job ,18.

${ }^{96}$ The oracles of Jeremiah began to be collected at the end of the seventh century and the first half of the sixth century, but the final form of the book can be dated approximately at the end of the Babylonian exile or soon after it (Sharp, Prophecy and Ideology in Jeremiah, 1-7).

${ }^{97}$ Janda, “Cognitive Linguistics in the Year 2015”, 134-135; Fitch, The Evolution of Language, 122-125; Lakoff and Johnson, Metaphors We Live By, 3-6.

${ }^{98}$ Janda, “Cognitive Linguistics in the Year 2015”, 140-141.
} 
as the substantial human experience that gives rise to a wide variety of abstract and theological connotations that serve as grammatical expressions of experiential faith that implies a parental relationship with God. ${ }^{99}$

These "semantic lines" give a broader significance to the notions of security, trust, fidelity, and truth expressed in the nifal and hifil of and its derived forms or cognate substantives. These semantic interrelations between qal and the other forms of the Hebrew root have been neglected and marginalized at a philological and theological level. Through this theological essay I tried to emphasize the parental notion of the care and nourishment of a defenseless child, e.g., Israel, as the basic semantic substratum (source cognitive domain) upon which all the diverse semantic nuances of the verb אָָ derive, making more evident the personal and exclusive relationship that exists between Israel and YHWH.

Therefore, the experience of faith in Israel is based upon a relationship of love with YHWH who is father and mother conjointly. According to this line of thought, one may comprehend all the metaphors and expressions of God's love as manifested in the Psalms, the neviim, and the expressions of faith through Jesus' parental relationship with his Father as revealed in the writings of the New Testament. ${ }^{100}$

\section{Bibliography}

Albright, William Foxwell. "A Prince of Taanach of the Fifteenth Century." Bulletin of the American Schools of Oriental Research 94 (1944): 12-27.

Alfaro, Juan. "Fides in terminologia biblica." Gregorianum 42, No.3 (1961): 463-505. Andrason, Alexander, and Christo H. J. Van Der Merwe. "The Semantic Potential of Verbal Conjugations as a set of Polysemous Senses: The Qatal in Genesis." Hebrew Studies 56 (2015): 71-88.

Arnold, T. Bill and John H. Choi. A Guide to Biblical Hebrew Syntax. New York (NY): Cambridge University Press, 2007.

Beal, Timothy. Esther. Berit Olam. Collegeville (MN): Liturgical Press, 1999.

Blenkinsopp, Joseph. Isaiah 40-55. New York-London-Toronto: Doubleday, 2000. . Isaiah 56-66. A New Translation with Introduction and Commentary. New York-London-Toronto: Doubleday, 2003.

\footnotetext{
${ }^{99}$ Lakoff and Johnson, Metaphors We Live By, 25-26; Bybee, Perkins and Pagliuca, The Evolution of Grammar. Tense, Aspect, and Modality in the Languages of the World, 15-17.

${ }^{100}$ See Hosea 11,1-9 and Ps 72,19-22.
} 
Brown, Francis, Samuel Rolles Driver, and Charles Briggs. Hebrew and English Lexicon of the Old Testament. Oxford: Clarendon Press, 1906 (1951).

Bruckner, James K. Exodus. Peabody (MA): Hendrickson Publishers, 2008.

Brueggermann, Walter. Deuteronomy. Nashville (TN): Abingdon Press, 2001.

Bybee, Joan, Revere Perkins, and William Pagliuca. The Evolution of Grammar. Tense, Aspect, and Modality in the Languages of the World. Chicago (IL)-London: Chicago University Press, 1994.

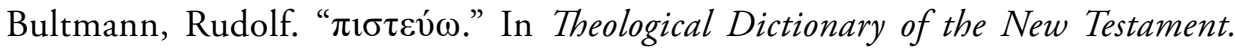
edited by G. Friedrich, Vol. VI, 174-182. Grand Rapids (MI): Eerdmans Publishing Co., 1973.

Campbell, Anthony and Mark O'Brien. Unfolding the Deuteronomistic History. Minneapolis (MN): Fortress Press, 2000.

Childs, Brevard S. Childs, Introduction to the Old Testament as Scripture. Minneapolis (MN): Fortress Press, 2010. . Isaiah. Louisville (KY)-London: Westminster John Knox Press, 2001.

Cross, Frank Moore. Canaanite Myth and Hebrew Epic. Essays in the History of the Religion of Israel. Cambridge (MA)-London (UK): Harvard University Press, 1997.

Durham, John. Exodus. Waco (TX): Word Books, 1987.

Eichrodt, Walther. Theology of the Old Testament. Vol. II. Old Testament Library. Philadelphia (PA): Westminster Press, 1967.

Evans, Vyvyan and Melanie Green. Cognitive Linguistics. An Introduction. Edinburg: Edinburg University Press, 2006.

Fitch, Tecumseh W. The Evolution of Language. New York (NY): Cambridge University Press, 2010.

Friedberg, Albert D., and Vincent De Caen. "Dating the Composition of the Book of Esther. A Response to Larsson”. Vetus Testamentum 53, No. 3 (2003): 427-429.

Gerleman, Gillis. Esther. Neukirchen-Vluyn: Neukirchener Verlag, 1982.

Gesenius, Heinrich Friedrich Wilhelm. "אָָָָ". In Hebrew-Chaldee Lexicon of the Old Testament, 58-59. Grand Rapids (MI): Baker Books, 2000.

Gomola, Aleksander. "From God is a Father to God is a Friend. Conceptual Integration in Metaphors for God in Christian Discourse." In Applications of Cognitive 
Linguistics: Cognitive Linguistics in Action: From Theory to Application and Back, edited by Elzbieta Tabakowska, Michal Choinski, and Lukasz Wiraszka, 387-407. Berlin-New York (NY): Mouton de Gruyter, 2010.

Gray, John. I-II Kings. A Commentary. Philadelphia (PA): Westminster Press, 1970.

Janda, Laura A. "Cognitive Linguistics in the Year 2015." Cognitive Semantics 1, No. 1 (2015): 131-154.

Jepsen, Alfred. "אַָָׁ". In Theological Dictionary of the Old Testament. Vol. I, edited by J. Botterweck and H. Ringgren, 292-323. (MI): Eerdmans Publishing Co., 1974.

. " "דָָָּ." In Theological Dictionary of the Old Testament. Vol. II, edited by J. Botterweck and H. Ringgren, 88-94. Grand Rapids (MI): Eerdmans Publishing Co., 1977.

Joüon, Paul. Ruth. Commentaire philologique et exégétique. Roma: Biblical Institute Press, 1986.

Joüon, Paul and Takamitsu Muraoka. A Grammar of Biblical Hebrew. 2 vols. Roma: Pontificio Istituto Biblico, 2000.

Kaiser, Otto. Der Prophet Jesaja Kapitel 13-19. Das Alte Testament Deutsch. Göttingen: Vandenhoeck \& Ruprecht, 1983.

Knierim, Rolf and George W. Coats. Numbers. The Forms of the Old Testament Literature. Vol. IV. Grand Rapids (MI)-Cambridge (UK): Eerdmans Publishing Co., 2005.

Koehler, Ludwig, Walter Baumgartner and Johann Jakob Stamm. "אמן." The Hebrew and Aramaic Lexicon of the Old Testament. Vol. I, 63-64. Leiden-Boston-Köln: Brill, 2001.

Lakoff, George. "Conceptual Metaphor. Contemporary Theory of Mataphor." In Cognitive Linguistics: Basic Readings, edited by Dirk Geeraerts, René Dirven, and John R. Taylor, 185-238. Berlin-New York: Mouton de Gruyter, 2006.

Lakoff, George, and Mark Johnson. Metaphors We Live By. Chicago (IL): University of Chicago, 1980.

Levenson, Jon. Esther. A Commentary. Louisville (KY): Westminster John Knox Press, 1997.

Lundbom, Jack. Jeremiah 37-52. A New Translation with Introduction and Commentary. New York-London-Toronto: Doubleday, 2004. 
. Deuteronomy. A Commentary. Grand Rapids (MI)-Cambridge (UK): Eerdmans Publishing Co., 2013.

Mabee, Charles. "Judicial Instrumentality in the Ahimelech Story." In Early Jewish and Christian Exegesis: Studies in Memory of William H. Brownlee, edited by Craig A. Evans and William F. Stinespring, 17-32. Atlanta (GA): Scholars Press, 1987. Mandelkern, Solomon. Veteris Testamenti Concordantiae Hebraicae atque Chaldaicae. Royal Oak (MI): ReInk Books, 2017 (1909).

McCarter, Peter K. I Samuel: A New Translation with Introduction, Notes and Commentary. Anchor Bible 8. Garden City (NY): Doubleday, 1980.

McKeown, James. Ruth. Grand Rapids (MI)-Cambridge (UK): Eerdmans Publishing Co., 2015.

Meyers, Carol. Exodus. New York (NY): Cambridge University Press, 2005.

Moberly, Walter. "אמן." In New International Dictionary of Old Testament Theology and Exegesis. Vol. I, edited by W. Van Gemeren, 427-433. Grand Rapids (MI): Zondervan, 1997.

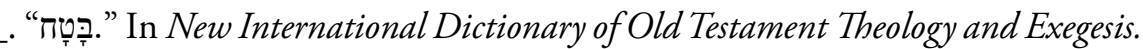
Vol. I, edited by W. Van Gemeren, 644-649. Grand Rapids (MI): Zondervan, 1997.

Motyer, Alec J. Isaiah. An Introduction and Commentary. Downers Grove (IL): InterVarsity Press, 2009.

Nelson, Richard. Deuteronomy. A Commentary. Louisville (KY)-London: Westminster John Knox Press, 2002.

Niskanen, Paul V. Isaiah 56-66. Collegeville (MN): Liturgical Press, 2014.

Noth, Martin. Numbers. A Commentary. Philadelphia: Westminster Press, 1968.

Nöth, Winfried. Handbook of Semiotics. Bloomington (IN): Indiana University Press, 1995.

Oswalt, John N. The Book of Isaiah. Chapters 40-66. Grand Rapids (MI)-Cambridge (UK): Eerdmans Publishing Co., 1998.

Reid, Debra. Esther. An Introduction and Commentary. Downers Grove (IL): InterVarsity Press, 2008.

Richter, Sandra. "Deuteronomistic History." In Dictionary of the Old Testament Historical Books, edited by Bill T. Arnold and Hugh G. M. Williamson, 219-230. Downers Grove (IL)-Leicester (UK): InterVarsity Press, 2005. 
Sasson, Jack. Ruth. A New Translation with a Philological Commentary and a Formalist-Folklorist Interpretation. Baltimore (MD)-London (U.K.): John Hopkins University Press, 1979.

Schaefer, Konrad. Psalms. Collegeville (MN): Liturgical Press, 2001.

Seebass, Horst. Numeri. Biblischer Kommentar Altes Testament. 2 vols. NeukirchenVluyn: Neukircherner Verlag, 2003.

Sharp, Carolyn J. Prophecy and Ideology in Jeremiah. Struggles for Authority in the Deutero-Jeremianic Prose. London (U.K.)-New York (NY): T\&T Clark, 2003.

Sneed, Mark R. The Social World of the Sages. An Introduction to Israelite and Jewish Wisdom Literature. Minneapolis (MN): Fortress Press, 2015.

Soulen, Richard and Kendall Soulen. Handbook of Biblical Criticism. Louisville (KY)-London (U.K.): Westminster John Knox Press, 2001.

Stuhlmuller, Carroll. "Deutero-Isaiah and Trito-Isaiah". In The New Jerome Biblical Commentary, edited by Raymond Brown. Bangalore: Theological Publications in India, 2011.

Thompson, Michael. Isaiah 40-66. Eugene (OR): Wipf and Stock, 2001.

Tsumura, David Toshio. The First Book of Samuel. Grand Rapids (MI)-Cambridge (UK): Eerdmans, 2007.

Vatican Council II. "Dogmatic Constitution Dei Verbum on Divine Revelation." Vatican, http://www.vatican.va/archive/hist_councils/ii_vatican_council/ documents/vat-ii_const_19651118_dei-verbum_en.html (accessed February 28, 2017).

Verburg, Pieter. Language and its Functions. Amsterdam-Philadelphia (PA): John Benjamins Publishing Company, 1998.

Von Rad, Gerhard. Genesis. A Commentary. Old Testament Library. Philadelphia (PA): Westminster Press, 1972.

. Teologia dell'Antico Testamento. Vol. 1. Teologia delle tradizioni storiche d'Israele. Brescia: Paideia Editrice, 1972.

. Teologia dell'Antico Testamento. Vol 2. Teologia delle tradizioni profetiche d'Israele. Brescia: Paideia Editrice, 1974.

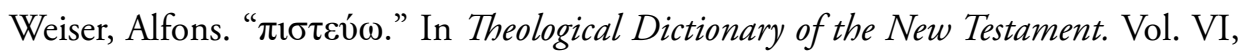
edited by G. Friedrich, 182-196. Grand Rapids (MI): Eerdmans Publishing Co., 1973. 
Weiser, Arthur. The Psalms. A Commentary. Philadelphia (PA): Westminster Press, 1962.

Westermann, Claus. Isaiah 40-66. A Commentary. The Old Testament Library. Philadelphia: Westminster Press, 1969.

Wildberger, Hans. "אמן." In Theological Lexicon of the Old Testament. Vol. I, edited by E. Jenni and C. Westermann, 134-157. Peabody (MA): Hendrickson Publishers, 2004.

___ "Glauben im AT." Zeitschrift für Theologie und Kirche 65 (1968): 129-159. . Isaiah 1-12. A Continental Commentary. Minneapolis (MN): Fortress Press, 1990.

. Isaiah 28-39. A Continental Commentary. Minneapolis (MN): Fortress Press, 1990.

Wilson, Andrew. The Nations in Deutero-Isaiah. A Study on Composition and Structure. Queenston (ON)-Lewiston (NY): Edwin Mellen Press, 1986. 